\title{
The Need for a New Approach to Federal Preemption of Union Members' State Law Claims
}

\author{
Stephanie R. Marcus
}

In Lingle v. Norge Division of Magic Chef, ${ }^{1}$ the Supreme Court decided that section 301 of the Labor Management Relations Act of 1947 (LMRA) ${ }^{2}$ did not preempt an Illinois employee's state law retaliatory discharge claim. Section 301 gives the federal courts jurisdiction over lawsuits arising from collective bargaining agreements (GBA's). ${ }^{3}$ Lingle attempted to clarify section 301's preemptive scope, but the decision has actually caused continued uncertainty in section 301 preemption cases. Although the Court held that plaintiff's state law claim was not preempted, its language potentially broadened section 301's preemptive power. This Note argues that courts should use a narrower test in section 301 preemption cases: If a union member's cause of action does not depend on the existence of a CBA, then his claim should not be preempted.

Over the past several decades, federal preemption of state labor law has been one of the most confused areas of federal court litigation. ${ }^{4}$ Section 301 cases have constituted a large part of this litigation, especially as states have passed more laws protecting employees. A section 301 controversy commonly occurs when a union member covered by a CBA files a complaint in state court and his employer raises the defense that section 301 preempts the employee's claim. If a case involving a section 301 issue is removed to federal court, ${ }^{5}$ the federal court can assert its jurisdiction to

1. 108 S. Ct. 1877 (1988).

2. 29 U.S.C. $\$ \S 141-97$ (1982 \& Supp. V 1987). Section 301 of the LMRA is codified at 29 U.S.C. $\$ 185$ (1982).

3. 29 U.S.C. $\$ 185$ (1982).

4. See, e.g., Cox, Recent Developments in Federal Labor Law Preemption, 41 OHо ST. L.J. 277,277 (1980) [hereinafter Recent Developments] ("In the field of industrial relations there has been more than thirty years of fighting over the boundary lines defining the realm of exclusive federal control."); Gregory, The Labor Preemption Doctrine: Hamiltonian Renaissance or Last Hurrah?, 27 WM. \& MARY L. Rev. 507, 565-66 (1986).

5. Cases where the plaintiff asserts a state law claim and the defendant raises a $\S 301$ defense can sometimes be removed to federal court on diversity grounds. 28 U.S.C. $\$ 1441$ (a) (1982). The case can also be removed if the plaintiff asserts any federal claim in addition to the state law claim. 28 U.S.C. $\S 1441$ (c) (1982). Once the case is removed, the federal court can then decide the state law claim(s) under its pendent jurisdiction. See F. James and G. Hazard, Civil Procedure $\$ 2.7$ (3d ed. 1985). The plaintiff's state court action cannot be removed solely on the basis of the defendant's assertion of a federal question in his defense. See id. at $\$ 2.6$. However, the "complete pre-emption 
resolve the dispute. If the defendant does not remove the case to federal court, a state court has concurrent jurisdiction to decide section 301 claims. $^{6}$

In Lingle, the Supreme Court concluded that the plaintiff's state law remedy for retaliatory discharge was "independent' of the collectivebargaining agreement in the sense of 'independent' that matters for $\S 301$ pre-emption purposes: resolution of the state-law claim does not require construing the collective-bargaining agreement." At the conclusion of his opinion for the Court, Justice Stevens summarized the current test for section 301 preemption: "[W]e hold that an application of state law is pre-empted by $\S 301$ of the Labor Management Relations Act of 1947 only if such application requires the interpretation of a collectivebargaining agreement."

According to the Court's earlier ruling in Allis-Chalmers v. Lueck, ${ }^{9}$ a plaintiff's claim is preempted if it is "substantially dependent upon analysis of the terms of an agreement made between the parties in a labor contract." ${ }^{10}$ This contrasts with the Court's language in Lingle, which indicates that claims requiring any interpretation or analysis of a CBA are preempted. ${ }^{11}$ The Lingle standard will create difficulties when the plaintiff asserts a claim completely separate from the CBA but the defendant cites CBA provisions as a defense. ${ }^{12}$ If the plaintiff asserts an independent or nonnegotiable state law claim, ${ }^{13}$ resolution of that claim is not

corollary to the well-pleaded complaint rule" modifies this proposition: If a CBA clause forms the basis for the plaintiffs claim, that claim is "purely a creature of federal law, notwithstanding the fact that state law would provide a cause of action in the absence of $\$ 301$." Caterpillar, Inc. v. Williams, 482 U.S. 386, 393-94 (1987) (quoting Franchise Tax Bd. of Cal. v. Construction Laborers Vacation Trust for S. Cal., 463 U.S. 1, 23 (1983)).

6. Charles Dowd Box Co. v. Courtney, 368 U.S. 502, 505 (1962) (state courts have concurrent jurisdiction over $\$ 301$ claims, although they must apply federal law in deciding such claims).

7. Lingle v. Norge Div. of Magic Chef, 108 S. Ct. 1877, 1882 (1988).

8. Id. at 1885 .

9. 471 U.S. 202 (1985).

10. Id. at 220 .

11. The Court stated in a footnote: "It is conceivable that a State could create a remedy that, although nonnegotiable, nonetheless turned on the interpretation of a collective-bargaining agreement for its application. Such a remedy would be preempted by $\S 301 . "$ Lingle, 108 S. Ct. at 1882 n.7. Also, as stated earlier, the Court asserted that Lingle's claim was not preempted because "resolution of [her] . . . claim does not require construing the collective-bargaining agreement," id. at 1882, thereby indicating that her claim would have been preempted if it did require CBA interpretation. Although this broad language was technically dicta, it has affected lower courts' adjudication of section 301 cases. See infra section IID.

12. See infra text accompanying notes $62-77,87-91,95-96$.

13. For the purposes of the proposed preemption test an "independent" state law claim is one that an employee can bring without any employment contract. To be independent, the claim cannot arise from contractual rights or implied contractual rights. A state law right therefore is not independent and is preempted if no cause of action would exist without a CBA. See discussion of Allis-Chalmers, infra section IIA(2). This definition of "independent" is different from the Court's use of the term in Lingle-where "independent" means that no CBA interpretation is necessary. In the proposed test a claim can still be "independent" even if its resolution requires CBA interpretation. Additionally, an independent right can be negotiable or nonnegotiable. A negotiable state law right is independent if it does not arise from the CBA and only the employer's defense mandates interpreting the CBA.

A nonnegotiable claim involves a state law right that cannot be altered by contract. A state statutory 
"substantially dependent" on CBA analysis because a court can base its decision on independent state law standards. However, that claim may involve interpretation of the CBA to judge the validity of the respondent's defense. Under a strict reading of the Court's language in Lingle, this type of claim appears to be preempted because it requires CBA interpretation. This could allow employers to assert invalid defenses under the CBA simply to force a court to rule that the plaintiff's claim is preempted.14

This Note argues that the Supreme Court's recent decision in Lingle reaches the correct result without using the most clear and equitable approach. Section I explains why section 301 should have a more limited role in the overall scheme of federal preemption of state labor law. Section II describes how the Lingle ruling broadens the scope of section 301 preemption developed in prior Supreme Court decisions. It also demonstrates that Lingle has not ended the confusion among circuit courts in deciding section 301 cases. Section III advocates that courts adopt a new model for determining whether section 301 preempts state law claims.

\section{Federal Preemption in the Labor Law Field}

Section 301 preemption represents a limited part of the larger scheme of federal preemption in the labor law field. The Constitution permits Congress to regulate labor relations in industries that affect commerce $^{15}$

claim is nonnegotiable unless the statute provides that unions can waive employees' rights in a CBA. Similarly, a state common law claim is nonnegotiable unless the state courts have interpreted it as waivable in contract. As the Supreme Court stated in Allis-Chalmers, "Clearly, $\$ 301$ does not grant the parties to a collective bargaining agreement the ability to contract for what is illegal under state law." 471 U.S. at 212 . State legislatures sometimes explicitly provide that certain statutory rights cannot be changed by contract.

Nonnegotiable state law rights are therefore independent of CBA's by definition: they cannot be altered by CBA negotiations. However, not all independent rights are nonnegotiable. Section 301 should not preempt nonnegotiable or independent negotiable state law claims.

14. See infra text accompanying notes 62-77, 87-91, 95-96. For example, a plaintiff can assert a nonnegotiable state law claim such as handicap discrimination, which does not rely on the CBA or require the court to conclude that the CBA was breached. The employer, however, can argue that his actions were based on the plaintiff's breach of a CBA provision and that he therefore had no discriminatory intent. In such a case, the plaintiff's state law claim is independent of the CBA, but the employer's defense requires CBA interpretation. This Note argues that such claims should not be preempted by $\S 301$ because they do not arise from a breach of contract. This part of the test is analogous to the "well-pleaded complaint" rule used in determining federal removal jurisdiction, which provides that "a defendant cannot, merely by injecting a federal question into an action that asserts what is plainly a state-law claim, transform an action into one arising under federal law, thereby selecting the forum in which the claim shall be litigated." Caterpillar v. Williams, 482 U.S. 386,399 (1987). The proposed test goes further, however, in that it provides that a plaintiff's claim is not preempted even if one of its elements requires CBA interpretation. In addition, the proposed test follows "the complete preemption corollary to the well-pleaded complaint rule" discussed supra note 5 , which provides that even if a plaintiff asserts his claim under state law, if it is based on a CBA violation, it is preempted by $\S 301$. See, e.g., Allis-Chalmers v. Lueck, 471 U.S. 202 (1985) (preemption of plaintiff's state law tort cause of action for bad faith handling of insurance claim); infra section IIA(2).

15. U.S. ConsT. art. I, § 8, cl. 3; see, e.g., NLRB v. Jones \& Laughlin Steel Corp., 301 U.S. 1 (1937). 
and grants Congress the power to preempt state labor laws through the supremacy clause. ${ }^{16}$ Several major pieces of legislation establish the basis for federal labor law. ${ }^{17}$ Most preemption cases fall under the NLRA, which encompasses the two main labor law preemption doctrines apart from section 301 suits.

\section{A. Section 301's Place in the Preemption Scheme}

Compared to other forms of preemption under the NLRA, section 301's scope should be clear-cut. It is only supposed to preempt causes of action that rely on a CBA. This is not so simple an issue as it may seem, however. Sometimes it is unclear whether a plaintiff's state law claim is directly based upon interpretation of a CBA.

By enacting section 301, Congress gave federal courts jurisdiction over disputes concerning labor contracts. Section 301 states in relevant part:

Suits for violation of contracts between an employer and a labor organization representing employees in an industry affecting commerce .... or between any such labor organizations, may be brought in any district court of the United States having jurisdiction of the parties, without respect to the amount in controversy or without regard to the citizenship of the parties. ${ }^{18}$

This language is very straightforward. Section 301 applies to "suits for violation of contracts." Preemption should therefore occur only when a plaintiff's cause of action is clearly for violation of a CBA.

When a court considers whether section 301 preempts a state law action, its determination is distinct from other types of preemption analysis. ${ }^{19}$ As the following two sections demonstrate, these other preemption doctrines invalidate state laws that interfere with the NLRA's purposes. Therefore, section 301 cases need not address whether a state law itself contradicts congressional intent as expressed in the NLRA.

16. "This Constitution, and the Laws of the United States which shall be made in Pursuance thereof . . . shall be the supreme Law of the Land; and the Judges in every State shall be bound thereby, any Thing in the Constitution or Laws of any State to the Contrary notwithstanding." U.S. ConsT. art. VI, cl. 2.

17. Labor Management Relations Act, 29 U.S.C. $\$ \$ 141-97$ (1982 \& Supp. V 1987) (incorporates and amends the NLRA); National Labor Relations Act, 29 U.S.C. $\$ \S 151-69$ (1982 \& Supp. V 1987) [hereinafter NLRA]; Labor-Management Reporting and Disclosure Act, 29 U.S.C. \$\$ 401-531 (1982 \& Supp. V 1987)) [hereinafter LMRDA]; Railway Labor Act, 45 U.S.C. §§ 151-88 (1982 \& Supp. V 1987).

18. 29 U.S.C. $\S 185$ (a) (1982). As this provision shows, section 301 covers cases brought by unions and employers as well as by employees. This Note addresses only individual employees' suits.

19. See infra notes $20-30$ and accompanying text. 


\section{B. Other Preemption Doctrines}

One of the two major theories of labor law preemption involves the primary jurisdiction of the National Labor Relations Board (NLRB). ${ }^{20}$ The leading Supreme Court case in this area is San Diego Building Trades Council v. Garmon. ${ }^{21}$ In Garmon, the Court ruled that

[w]hen it is clear or may fairly be assumed that the activities which a State purports to regulate are protected by $\S 7$ of the National Labor Relations Act, or constitute an unfair labor practice under $\S 8$, due regard for the federal enactment requires that state jurisdiction must yield. ${ }^{22}$

In fact, the Court expanded this restriction to conduct that is "arguably" protected by section 7 or prohibited by section $8 .^{23}$

Lodge 76, Machinists v. Wisconsin Employment Relations Commis$\operatorname{sion}^{24}$ represents the theory behind the other major line of federal labor law preemption cases. ${ }^{25}$ In Machinists, the Supreme Court ruled that the NLRA preempted a Wisconsin state law empowering the state labor board to enjoin union members from refusing to work overtime. The Court based its ruling on the principle that state laws could not regulate activities that Congress meant to be left as economic weapons for labor and management. ${ }^{26}$ Thus, if certain state laws avoid preemption under sections 7 and 8 of the NLRA, they might still be preempted under the Machinists test.

Machinists preemption also affects state laws that may interfere with the negotiation or enforcement of a CBA. ${ }^{27}$ For example, in Local 24, International Brotherhood of Teamsters $v$. Oliver ${ }^{28}$ the Court ruled that an Ohio antitrust law was preempted because its application "would frustrate the parties' solution of a problem which Congress has required them to negotiate in good faith toward solving, and in the solution of which it

20. See, e.g., A. Cox, D. Bok \& R. Gorman, Cases and Materials on Labor Law 892-922 (1986) (subchapter on preemption of state labor law); Cox, Labor Law Preemption Revisited, 85 Harv. L. Rev. 1337, 1337-51 (1972) [hereinafter Preemption Revisited]; Comment, Employment AtWill in the Unionized Setting, 34 CATH. U.L. REv. 979, 990-93 (1985).

21. 359 U.S. 236 (1959).

22. Id. at 244 .

23. Id. at 245. Section 7 of the NLRA protects workers' "right to self-organization, to form, join, or assist labor organizations, to bargain collectively through representatives of their own choosing, and to engage in other concerted activities for the purpose of collective bargaining or other mutual aid or protection . . . " 29 U.S.C. $\$ 157$ (1982). Section 8 prohibits a variety of unfair labor practices. 29 U.S.C. $\$ 158(1982)$.

24. 427 U.S. 132 (1976).

25. See, e.g., Comment, supra note 20, at 993-95; A. Cox, D. Bok \& R. Gorman, supra note 20.

26. Machinists, 427 U.S. at $140-41,155$.

27. See generally Comment, NLRA Preemption of State Wrongful Discharge Claims, 34 HasTINGs L.J. 635, 644-47 (1983) (describing two types of preemption that fall under Machinists analysis: "bargaining process preemption" and "bargaining agreement preemption").

28. 358 U.S. 283 (1959). 
imposed no limitations relevant here."28 Oliver held that a state cannot pass a law that significantly interferes with mandatory bargaining subjects such as wages, hours, and working conditions.

In later cases, however, the Court narrowed the Oliver, Garmon, and Machinists preemption holdings by providing for various exceptions. ${ }^{30}$ The states therefore retain the power to regulate employment relations in areas that Congress did not intend to leave solely to federal law or the arbitration system. Because of the scope of the Garmon and Machinists preemption doctrines, section 301 cases do not need to address the issue of the state law's validity. Disputes about section 301 preemption involve a completely separate analysis in which courts should decide only whether the plaintiff's claim directly arises from a CBA breach.

\section{The Federal Courts' Approach to Section 301 PREEMPTION}

\section{A. Supreme Court Jurisprudence Prior to Lingle}

The Supreme Court's decision in Lingle represents the current standard for judging section 301 cases. Lingle's test that a plaintiff's state law action avoids preemption if it is (a) based on a nonnegotiable state law right, and (b) independent from interpretation of a CBA, extends the scope of prior Supreme Court decisions defining section 301's limits.

\section{Lincoln Mills and Lucas Flour}

Ten years after Congress passed the LMRA, the Supreme Court ruled that section 301 authorized the courts to develop a federal common law of interpreting CBA's." By examining the "somewhat cloudy and confusing"32 legislative history of section 301, the Court concluded that Congress intended that federal courts have the authority to enforce CBA's. Although Lincoln Mills did not address the question of preemption, it set

29. Id. at 296 .

30. See, e.g., Metropolitan Life Ins. Co. v. Massachusetts, 471 U.S. 724 (1985) (Massachusetts law providing minimum health care benefits for insured workers not preempted, limiting scope of Machinists preemption); New York Tel. Co. v. New York Dep't of Labor, 440 U.S. 519 (1979) (New York law providing unemployment benefits to workers eight weeks after their employment ended by strike not preempted); Malone v. White Motor Corp., 435 U.S. 497 (1978) (Minnesota law requiring pension funding charge to employers ending pension plan not preempted by NLRA, even if it contradicts CBA terms, because Congress intended that states be allowed to regulate pension plans); Sears, Roebuck \& Co. v. San Diego County Dist. Council of Carpenters, 436 U.S. 180 (1978) (California state courts have power to enjoin union picketing on Sears' property in absence of charge filed with NLRB); Farmer v. United Bhd. of Carpenters and Joiners, Local 25, 430 U.S. 290 (1977) (plaintiff's state law claim for intentional infliction of emotional distress unpreempted; exception to Garmon analysis); see also Cox, Recent Developments, supra note 4, at 279-96 (discussing Sears and New York Telephone).

31. Textile Workers Union v. Lincoln Mills of Ala., 353 U.S. 448 (1957).

32. Id. at 452 . 
the stage for later preemption cases by establishing the importance of applying federal law in interpreting CBA's.

The Supreme Court first decided whether section 301 preempts state law in Local 174, Teamsters of America v. Lucas Flour Co ${ }^{33}$ Lucas Flour held that state courts could not apply local contract law to enforce CBA's. Reversing the Supreme Court of Washington, the Court ruled that " $[t]$ he dimensions of $\S 301$ require the conclusion that substantive principles of federal labor law must be paramount in the area covered by the statute."34 The Washington state court therefore should have applied federal contract law to resolve the dispute.

The results of Lincoln Mills and Lucas Flour are fairly straightforward: Section 301 authorizes the courts to establish a federal common law for interpreting CBA's, and states cannot use local rules to resolve breach of CBA disputes. Controversy arises, however, when a plaintiff brings a claim that does not sound in breach of contract, but nevertheless implicates the CBA. Because of confusion among state and federal courts over how to resolve this issue, the Supreme Court has attempted to define the parameters of section 301 preemption.

\section{Allis-Chalmers v. Lueck}

The confusion among circuit courts leading to the Supreme Court's grant of certiorari in Lingle stemmed from the Court's decision in AllisChalmers Corp. v. Lueck. ${ }^{35}$ In Allis-Chalmers, the Court ruled that section 301 preempted a Wisconsin employee's state law cause of action for bad faith handling of an insurance claim. Wisconsin courts recognized the bad faith handling of insurance claims as a tort under state law. The Supreme Court held that this state law tort could not extend to employees covered by a CBA.

Instead of attempting to solve his problem through the CBA grievance procedure, plaintiff Lueck filed a claim in Milwaukee County Circuit Court. ${ }^{36}$ His complaint stated that Allis-Chalmers and Aetna Insurance Company breached their duty of good faith by failing to pay his disability benefits as provided in the CBA. ${ }^{37}$ Although the trial court ruled that section 301 preempted Lueck's suit, the Wisconsin Supreme Court reversed on the principle that a bad faith tort claim is distinguishable under Wisconsin law from a bad faith breach of contract claim. Even though the breach of duty that constitutes the bad faith claim is based on contractual

\footnotetext{
33. 369 U.S. 95 (1962).

34. Id. at 103.

35. 471 U.S. 202 (1985). After Allis-Chalmers but prior to Lingle, the Court decided two other section 301 cases that applied the Allis-Chalmers preemption test: IBEW, AFL-CIO v. Hechler, 481 U.S. 851 (1987) and Caterpillar, Inc. v. Williams, 482 U.S. 386 (1987).

36. Allis-Chalmers, 471 U.S. at 206.

37. Id.
} 
rights, the Wisconsin court declared it independent of the CBA. ${ }^{38}$ The Supreme Court reversed. Its decision turned on whether the Wisconsin tort of bad faith was truly independent from interpretation of the CBA:

Our analysis must focus, then, on whether the Wisconsin tort action for breach of the duty of good faith as applied here confers nonnegotiable state-law rights on employers or employees independent of any right established by contract, or, instead, whether evaluation of the tort claim is inextricably intertwined with consideration of the terms of the labor contract. ${ }^{39}$

In evaluating Lueck's claim, the Court held that it was "inextricably intertwined" with the CBA. Since the tort of bad faith is based on the breach of implied contract rights, Lueck's claim was inseparable from interpretation of his GBA. Federal law therefore must resolve the dispute: "[I]t is a question of federal contract interpretation whether there was an obligation under this labor contract to provide the payments in a timely manner, and, if so, whether Allis-Chalmers' conduct breached that implied contract provision."

In Allis-Chalmers, the Court stressed the concern for maintaining the effectiveness of arbitration that it first articulated in Lucas Flour. If it had upheld the Wisconsin tort, which "not only derive[d] from the contract, but [was] defined by the contractual obligation of good faith,"41 employees would be free to bypass arbitration in cases that involved CBA interpretation. ${ }^{42}$ Thus, the Court concluded that section 301 preempts state law claims that are "substantially dependent upon analysis of the terms of an agreement made between the parties in a labor contract."

The "substantially dependent" test did not resolve the confusion surrounding section 301 cases, however. As the Court said in Allis-Chalmers, section 301 disputes would have to be decided on a case-by-case basis because of differences among state law claims and CBA terms. ${ }^{44}$ This caseby-case analysis led to inconsistency among the circuit courts.

38. Id. at 207.
39. Id. at 213.
40. Id. at 215.
41. Id. at 218.

42. When an employee files a state law claim, he does not need to have the claim arbitrated first, but if his claim arises under section 301 , he must exhaust his arbitration remedy or his claim will be dismissed. See, e.g., Vaca v. Sipes, 386 U.S. 171, 184 (1967) ("it is settled that the employee must at least attempt to exhaust exclusive grievance and arbitration procedures established by the bargaining agreement.") (citation omitted); Republic Steel Corp. v. Maddox, 379 U.S. 650 (1965) (same).

43. Allis-Chalmers, 471 U.S. at 220.

44. Id. 


\section{B. Conflict Among the Circuits After Allis-Chalmers}

Circuit courts interpreted the Allis-Chalmers approach to section 301 claims in conflicting ways. The disparity in approaches became evident in the courts' treatment of retaliatory discharge causes of action under state workers' compensation laws. To resolve the circuit split, the Supreme Court granted certiorari in Lingle v. Norge Division of Magic Chef..$^{45}$

Lingle required the Supreme Court to decide between two approaches to retaliatory discharge claims. The Second, Third, and Tenth Circuits had held that protection against retaliatory discharge is a nonnegotiable state law right that cannot be preempted by section $301,{ }^{46}$ whereas the Seventh and Eighth Circuits had ruled that section 301 does preempt retaliatory discharge claims because such claims are incorporated in CBA "just cause" provisions. ${ }^{47}$

\section{G. Lingle and the Current Test for Section 301 Preemption}

In Lingle, the Supreme Court opted to follow the Second, Third, and Tenth Circuits' holding that section 301 does not preempt state retaliatory discharge claims. Plaintiff Jonna Lingle had brought a state court claim against her employer, the Norge Division of Magic Chef, under the Illinois Workers' Compensation Act. Arbitration of her claim under the CBA was already in progress. ${ }^{18}$ The district court ruled that section 301 preempted her claim, and the court of appeals affirmed..$^{49}$ In his opinion for the Court, Justice Stevens defined the issue as "whether an employee covered by a collective-bargaining agreement that provides her with a contractual remedy for discharge without just cause may enforce her state law remedy for retaliatory discharge." 50 The Court concluded that Lingle could bring her claim in state court despite the CBA "just cause" provision. In reaching its decision, the Court cited the Allis-Chalmers preemption test, although the Court pointed out that the Seventh Circuit had

45. 108 S.Ct. 1877 (1988).

46. Baldracchi v. Pratt \& Whitney Aircraft Div., 814 F.2d 102, 105 (2d Cir. 1987) (employee's right under Connecticut statute prohibiting retaliatory discharge "absolute and cannot be waived" by the CBA, and employee's claim therefore not preempted); Herring v. Prince Macaroni, 799 F.2d 120, 124, n.2 (3d Cir. 1986) (employee's retaliatory discharge claim not preempted); Peabody Galion v. Dollar, 666 F.2d 1309, 1319-20 (10th Cir. 1981) (employee's retaliatory discharge claim not preempted; pre-Allis-Chalmers).

47. Lingle v. Norge Div. of Magic Chef, 823 F.2d 1031, 1041 (7th Cir. 1987) (Seventh Circuit "ha[s] consistently held that claims of retaliatory discharge brought by a worker who is covered by a collective bargaining agreement are actually claims for wrongful discharge under the collective bargaining agreement."); Johnson v. Hussmann Corp., 805 F.2d 795, 797 (8th Cir. 1986) (employee's retaliatory discharge claim preempted); Vantine v. Elkhart Brass Mfg. Co., 762 F.2d 511, 517 (7th Cir. 1985) (same).

48. Lingle, $108 \mathrm{~S}$. Ct. at 1878.

49. Id.

50. Id. at 1879 . 
misunderstood that test. ${ }^{51}$ The Court therefore tried to clarify the ruling of Allis-Chalmers.

The Seventh Circuit had declared Lingle's claim preempted since in a grievance proceeding under the CBA, an arbitrator would consider the same facts that the state court would judge in Lingle's claim under the Workers' Compensation Act. ${ }^{\mathbf{5 2}}$ Under the Allis-Chalmers standard, however,

even if dispute resolution pursuant to a collective-bargaining agreement, on the one hand, and state law, on the other, would require addressing precisely the same set of facts, as long as the state-law claim can be resolved without interpreting the agreement itself, the claim is "independent" of the agreement for $\S 301$ pre-emption purposes. $^{53}$

Since Lingle's rights under the Illinois Workers' Compensation Act were nonnegotiable, the court would not need to interpret the "just cause" provision of the CBA. As Justice Stevens explained:

For while there may be instances in which the National Labor Relations Act pre-empts state law on the basis of the subject matter of the law in question, [here the Court inserted a footnote about Garmon and Machinists preemption] $\S 301$ pre-emption merely ensures that federal law will be the basis for interpreting collective-bargaining agreements, and says nothing about the substantive rights a State may provide to workers when adjudication of those rights does not depend upon the interpretation of such agreements. ${ }^{54}$

Lingle's state law claim thus escaped preemption because it did not require interpretation of the CBA.

The Court reached the correct conclusion in Lingle. Previous Supreme Court decisions such as Lucas Flour and Allis-Chalmers called for section 301 preemption because they involved claims that were at heart breach of contract causes of action. ${ }^{\mathrm{bS}}$ In cases where the claim does not depend on a CBA for its existence, section 301 should have no preemptive force. Lingle tried to make this clear, but its approach has improperly increased the preemptive scope of section 301 by extending it to claims that are not based on breach of contract. ${ }^{\text {s6 }}$

Although Lingle held that a state law claim is not preempted just because it could have been brought under the CBA, the decision's language

51. Id. at 1881-83.

52. Id. at $1882-83$

53. Id. at 1883 .

54. Id. (footnotes omitted).

55. See supra text accompanying notes 33-44.

56. See infra text accompanying notes 71-87. 
broadened the Allis-Chalmers holding: Lingle announced that section 301 preemption occurs when a plaintiff's state law claim "requires the interpretation of a collective-bargaining agreement," while Allis-Chalmers called for section 301 preemption when resolution of the claim "is substantially dependent upon analysis" of the CBA terms. ${ }^{58}$ Under Lingle, a plaintiff's claim could therefore be preempted if it requires CBA interpretation only in assessing an employer's defense, whereas under AllisChalmers that claim would probably escape preemption because it does not "substantially depend" on CBA interpretation. Furthermore, the $\mathrm{Al}$ lis-Chalmers Court stressed the "narrow focus" of its decision since "[t]he full scope of the pre-emptive effect of federal labor-contract law remains to be fleshed out on a case-by-case basis."

Because the Lingle test could require courts to look at individual CBA's to decide whether section 301 preempts a plaintiff's claim, the pre-Lingle confusion is likely to continue. An examination of several post-Lingle circuit court cases shows the problems Lingle has created thus far.

\section{Post-Lingle Circuit Court Adjudication of Section 301 Cases}

\section{Cases Involving Recognized State Law Claims}

Circuit courts have inconsistently decided section 301 cases involving recognized state law claims. ${ }^{60}$ Although the Lingle decision did lead several courts of appeal to hold that section 301 does not preempt retaliatory discharge and handicap discrimination claims, ${ }^{61}$ the confusion surrounding section 301 remains. The following discussion of post-Lingle decisions demonstrates the need for a new section 301 preemption test.

In Smolarek v. Chrysler Corp., the Lingle ruling led the Sixth Circuit to reverse district court rulings in companion retaliatory discharge and handicap discrimination cases. ${ }^{62}$ The court of appeals ruled that plaintiff Fleming's retaliatory discharge cause of action was "essentially the same

57. Lingle, $108 \mathrm{~S}$. Ct. at 1885 (footnote omitted).

58. Allis-Chalmers v. Lueck, 471 U.S. 202, 220 (1985).

59. Id.

60. A recognized or established claim is one that the state courts have already accepted as viable under state statutory or common law. An unestablished claim is one that the state courts have not yet had the opportunity to address, making it unclear whether the claim is cognizable under state law.

61. See, e.g., Merchant v. American S.S. Co., 860 F.2d 204 (6th Cir. 1988) (section 301 does not preempt seaman's retaliatory discharge claim); Ackerman v. Western Elec. Co., 860 F.2d 1514 (9th Cir. 1988) (section 301 does not preempt plaintiff's handicap discrimination claim); Miller v. AT\&T Network Systems, 850 F.2d 543 (9th Cir. 1988) (en banc) (section 301 does not preempt plaintiff's handicap discrimination claim, but does preempt his claim for intentional infliction of emotional distress). However, this does not mean that all retaliatory discharge and handicap discrimination actions escape section 301 preemption. The analysis depends on the particular law. For example, some states could make such rights subject to negotiation or applicable to non-union workers only.

62. 879 F.2d 1326 (6th Cir. 1989). This case consolidated two separate lawsuits brought by employees Smolarek and Fleming against Chrysler. Although the case is officially named Smolarek v. Chrysler Corp., this Note's discussion focuses on Fleming's claims; for clarity the case will hereinafter be referred to as Fleming. 
as the claim that the [Supreme] Court addressed in Lingle," fore it was not preempted by section 301 .

Fleming's handicap discrimination claim presented a more complicated issue. ${ }^{64}$ Arguing for section 301 preemption, Chrysler asserted that the provisions of the Michigan Handicappers' Civil Rights Act (HCRA) that gave rise to Fleming's claim required CBA interpretation. Although the right to be free from handicap discrimination is nonnegotiable, Ghrysler sought to prove that in determining whether Fleming's right had been violated, "the HCRA itself requires reference to the 'terms, conditions, and privileges of employment." "6s Chrysler also tried to distinguish the HCRA from other states' anti-discrimination statutes because of its provision excluding from protection employees whose handicaps are related to their job performance. ${ }^{66}$

Rejecting Chrysler's arguments, the court ruled that Fleming's claim could be determined without reliance on the GBA. According to the court, Fleming had to show "(1) that Chrysler took adverse employment actions against him and (2) that the actions were motivated by his handicap" to establish a prima facie case under the HCRA. ${ }^{67}$ Interpretation of the CBA is irrelevant to these factual questions. If a court determined that Fleming's handicap motivated Chrysler's actions, Chrysler would be liable under the HCRA, regardless of the terms of the CBA. In its defense, Chrysler only had to prove that its motives were based on a factor other than Fleming's handicap.

The court summarized the central question as "What was Chrysler's motivation?"68 Chrysler would probably have argued that CBA terms motivated its actions. Yet interpretation of the CBA was unnecessary because "in light of this defense, a court need only decide whether Chrysler took actions adverse to Fleming because of his handicap or rather solely because Chrysler felt bound by the union agreement to take the actions or for some other legitimate reason." ${ }^{\text {" It }}$ was therefore "not necessary to

63. Id. at 1331.

64. Smolarek appealed the district court's denial of his motion to remand, while Fleming appealed the district court's decision that section 301 preempted his state law claims. Since Fleming's direct appeal forces the court of appeals to decide the preemption question, the following discussion will focus on Fleming's claim.

65. 879 F.2d at 1332. The relevant HCRA sections provide that an employer cannot "Id]ischarge or otherwise discriminate against an individual with respect to . . . the terms, conditions, or privileges of employment," " or

[1]imit, segregate, or classify an employee . . . in a way which deprives or tends to deprive an individual of employment opportunities or otherwise adversely affects the status of an employee because of a handicap that is unrelated to the individual's ability to perform the duties of a particular job or position.

Id. at 1331-32 (citing Mich. CoMp. Laws $\S 37.1202(1)(\mathrm{b})$,(c)).

66. Id. at 1332 .

67. Id. at 1334. Plaintiff therefore would not even need to refer to the CBA to establish a prima facie case.

68. Id.

69. Id. 
decide at the outset whether or not Chrysler's interpretation of the agreement is correct as a matter of federal labor law."70

The Sixth Circuit made a fine distinction between finding that Chrysler acted out of its obligations under the CBA and defining those CBA obligations: How can a court determine whether Chrysler acted according to the CBA if it does not interpret the CBA terms? According to the court, because Chrysler needed to prove only that Fleming's handicap did not motivate its actions, the CBA terms were irrelevant.

Although the Sixth Circuit reached the correct result, the Lingle test required it to strain to find that GBA interpretation was not necessary to resolve Fleming's claim. The court could just as easily have decided the case the opposite way under Lingle. Even if Chrysler's defense did require $\mathrm{CBA}$ interpretation, Fleming's claim should not have been preempted. His claim did not rely on a breach of the CBA, and Chrysler brought in the CBA terms as a defense. Under this Note's proposed approach, the court could have held that section 301 did not preempt Fleming's claim immediately after finding that the HCRA provided Fleming with independent state law rights.

Using the same Lingle preemption test, the Ninth Circuit decided a case that seems to contradict the Sixth Circuit's reasoning in Fleming. In Newberry v. Pacific Racing Association, ${ }^{71}$ the court ruled that section 301 preempted plaintiff Newberry's claim for intentional infliction of emotional distress." Newberry asserted that she "suffered humiliation, mental anguish, and emotional distress" " from the defendant's decision to terminate her " "with no direct evidence and without just cause to accuse [her] of theft and gross dereliction of duty" " after only "'a cursory investigation into various racetrack operations including those within [Newberry]'s position." "73

Intentional infliction of emotional distress is a tort claim recognized by California courts. ${ }^{74}$ The Ninth Circuit reasoned that Newberry's emotional distress claim depended upon interpretation of the CBA between her union and Pacific Racing Association. According to the Court, "it is clear that Newberry's emotional distress claim arises out of her discharge and the defendant's conduct in the investigation leading up to it." ${ }^{\text {"ss }}$ Since

70. Id. (emphasis in original). See also Bettis v. Oscar Mayer Foods Corp., 878 F.2d 192, 197 (7th Cir. 1989) (reasoning similar to Fleming).

71. 854 F.2d 1142 (9th Cir. 1988).

72. Id. at 1149-50. The court also ruled that section 301 preempted Newberry's breach of the covenant of good faith and fair dealing claim, but that is not controversial since the covenant of good faith and fair dealing is derived from and implied in the GBA.

73. Id. at 1149 (quoting plaintiff's complaint).

74. See, e.g., Cervantez v. J.C. Penney Co., 24 Cal. 3d 579, 593, 595 P.2d 975, 983, 156 Cal. Rptr. 198, 206 (1979) (court describes necessary elements for establishing prima facie case of intentional infliction of emotional distress); see also 6 CAL.JuR.3D (REv.), Assault and Other Wilful Torts \$§ 95-106 (1988).

75. Newberry, 854 F.2d at 1149. 
Newberry's CBA included a provision that employees could not be fired without just cause, her claim would require interpretation of the agreement's terms. Section 301 therefore preempted Newberry's claim.

Under the proposed test the Ninth Circuit would have come to the opposite conclusion. Newberry's claim could be assessed under independent state law standards without regard to her CBA. ${ }^{76}$ Even if the Pacific Racing Association's defense required CBA interpretation, Newberry's claim should not have been preempted. The court could have used federal law to interpret the CBA in evaluating Pacific's defense. It could have then proceeded to adjudicate Newberry's tort claim under state law standards. Newberry's claim was independent of the CBA, and her employer should not have been able to cause preemption by asserting a CBA-based defense. Although the court could have decided this case correctly under Lingle, the broad scope of the Lingle test caused it unnecessary confusion. ${ }^{77}$

76. As defined by California courts, a prima facie showing of intentional infliction of emotional distress includes three elements: "(1) extreme and outrageous conduct by the defendant with the intention of causing, or reckless disregard of the probability of causing, emotional distress; (2) the plaintiff's suffering severe or extreme emotional distress, and (3) actual and proximate causation of the emotional distress by the defendant's outrageous conduct." Cervantez, 24 Cal. 3d at 593, 595 P.2d at 983, $156 \mathrm{Cal}$. Rptr. at 206. In addition, "[c]onduct to be outrageous must be so extreme as to exceed all bounds of that usually tolerated in a civilized community." Id. Newberry's emotional distress claim could be evaluated under this state law standard without interpreting the CBA. The state law standard exists independent of any contract. See Comment, supra note 20, at 1005 (intentional infliction of emotional distress is "recognized cause[] of action under the California employment at-will doctrine"; employees without employment contracts can bring suits for intentional infliction of emotional distress).

77. Under the Lingle test, a claim is preempted only if it requires CBA interpretation. The state law standard for intentional infliction of emotional distress is independent of employment contracts. See supra note 76. Just as in Fleming, the question is a factual one of intent. In its defense, Pacific Racing Association must prove only that its actions were motivated by factors other than the intent to inflict emotional distress. Although Pacific might have wanted to use the "just cause" provision of the CBA as a defense to Newberry's claim, her claim concerned the manner in which Pacific terminated her employment and conducted an investigation of her conduct. Therefore, a "just cause" defense was not necessarily relevant, and even if it were, the court could decide that Pacific was motivated by its belief that it had "just cause" under the CBA.

Moreover, Newberry's claim implicated more than a wrongful discharge cause of action: Her allegations about the cursory investigation and the false accusation of "theft and gross dereliction of duty," "Newberry, 854 F.2d 1142 at 1149 (quoting plaintiff's complaint), could have been characterized as defamation causes of action as well. See, e.g., Tellez v. Pacific Gas \& Elec. Co., 817 F.2d 536 (9th Cir. 1987) (defamation and intentional infliction of emotional distress claims not preempted by section 301 since California defamation law establishes nonnegotiable rights and plaintiff's emotional distress claim can be determined without reference to GBA). Under the Lingle test, Newberry's claim therefore should not have been preempted because it did not require reference to the CBA.

The Seventh Circuit also recently held that section 301 preempted a plaintiff's intentional infliction of emotional distress claim. Douglas v. American Information Technologies Corp., 877 F.2d 565 (7th Cir. 1989). The court ruled that addressing the plaintiff's allegations of harassment, some of which overlapped with subjects covered by the CBA, required CBA interpretation: "Resolution of Ms. Douglas' claim will require a court to interpret the collective bargaining agreement in order to determine whether or not Illinois Bell's allegedly wrongful conduct was authorized under the collective bargaining agreement." Id. at 572. This kind of interpretation was only necessary to evaluate Bell's defense, and therefore Douglas' claim should not have been preempted.

Douglas' claim derived from the state law right to be free from intentional infliction of emotional distress, rather than from her CBA. Since Douglas could have brought this claim under state law without a CBA, her complaint would not be preempted under the proposed test. This does not mean that the CBA would be ignored in deciding Douglas' claim. The court would use federal law to 


\section{Cases Involving Non-Established State Law Claims}

The Lingle test has also caused problems for federal courts considering unestablished state law claims. The First Circuit case Jackson v. Liquid Carbonic Corp. ${ }^{78}$ provides an example of how the Lingle test incorrectly allows preemption of claims that are not based on breach of the CBA.

In Jackson, the plaintiff asserted that his employer's drug-testing program was a violation of his right to privacy under the Massachusetts Constitution and under a Massachusetts privacy statute. Focusing on Jackson's state statutory claim, the court first concluded that the Massachusetts Supreme Court had not recognized any nonnegotiable right to be free from drug-testing, although it had not explicitly rejected such a right. ${ }^{79}$ The court explained that in such circumstances it could proceed on the basis of how the Massachusetts Supreme Court would likely resolve plaintiff's claim. ${ }^{80}$

The First Circuit then applied the Lingle test and asked, "[C]an Jackson's privacy claim be made out without interpreting the Agreement?"'s The court concluded that CBA interpretation was necessary and ruled that section 301 preempted Jackson's claim. According to the court, certain drug-testing plans would violate Massachusetts law, but to determine whether a particular plan was illegal, the state court would undertake a balancing of factors, including the interpretation of a CBA. ${ }^{\mathbf{8 2}}$ The Court searched Jackson's CBA for any relevant provisions and concluded that interpretation of the contract's management rights clause was integral to resolving Jackson's claim. ${ }^{83}$

The First Circuit's approach may have been correct under Lingle, but it led to the undesirable result that Jackson's claim, which was not based on a CBA breach, was preempted. The court's analysis was faulty in several respects. First, as Judge Bownes pointed out in his dissent, "[i]t is for the Massachusetts courts to make [the] determination" whether state law provides an independent privacy right to be free from mandatory drug

\footnotetext{
interpret the CBA where it was relevant to Douglas' allegations and her employer's defense.

The Seventh Circuit, like the Ninth Gircuit (Compare Newberry with Tellez, supra), has not ruled that section 301 preempts all intentional infliction of emotional distress claims, however. See, e.g., Keehr v. Consolidated Freightways, 825 F.2d 133 (7th Cir. 1987) (plaintiffs' emotional distress claim based on defendant's verbal assaults not preempted). Adoption of this Note's proposed test would make courts' approach to preemption of intentional infliction of emotional distress claims more consistent.

78. 863 F.2d 111 (1st Cir. 1988). Other post-Lingle cases have also held that $\S 301$ preempts unestablished state law claims. See, e.g., Laws v. Calmat, 852 F.2d 430 (9th Cir. 1988) (section 301 preempts plaintiff's claim that employer's drug-testing program violated California constitution); Utility Workers of Am., Local 246 v. Southern Cal. Edison Co., 852 F.2d 1083 (9th Cir. 1988) (same).

79. 863 F.2d at 115.

80. Id. at 116 .

81. Id. at 114.

82. Id. at 117.

83. Id. at 120 .
} 
testing. ${ }^{84}$ Because this question was still unclear, Jackson's case should have been remanded to the state court. ${ }^{85}$

Second, Judge Bownes asserted that "there is nothing in the collectivebargaining agreement which even remotely deals with the subject of drug testing or privacy rights." make in applying the Lingle preemption approach: they look to the CBA to see if any of its clauses require interpretation. Courts instead should look only at the plaintiff's state law claim to decide the preemption question.

The First Circuit's analysis stemmed from its starting point of asking whether resolution of Jackson's claim required any CBA interpretation. Under this Note's proposed test, the court would have asked only whether Jackson's claim was based on a CBA breach or arose directly from the CBA. Clearly Jackson's claim did not fall under either of these categories, and therefore it should not have been preempted. Jackson claimed that the Massachusetts Constitution and a Massachusetts privacy statute protected him from mandatory drug testing. Preemption would have been proper only if Jackson had claimed that his employer violated the Massachusetts laws because the CBA guaranteed him the right to be free from drug testing.

In addition, while the First Circuit may have been right in predicting that Massachusetts courts would use a balancing test to resolve Jackson's claim under the privacy statute and that they would examine the CBA in this process, this use would only be in Liquid Carbonic (L-Corp)'s defense. The CBA was not an essential element of Jackson's claim, and the court explicitly recognized this by focusing on the management rights clause, which may or may not have given L-Corp the right to implement a drug-testing program. Since section 301 concerns suits for breaches of CBA's, it should not preempt causes of action that do not rely on a CBA violation for their existence. In short, the First Circuit's application of the Lingle test in Jackson gave section 301's preemptive power an overly broad scope.

Prior to Lingle, the Tenth Circuit used an approach to unestablished state law claims that is consistent with this Note's proposal and contrasts with the First Circuit's reasoning in Jackson. In United Assoc. of Journeymen, Local No. 57 v. Bechtel Power Corp. ${ }^{87}$ the court found that section 301 did not preempt plaintiffs' state law blacklisting claims, ${ }^{88}$ even

84. Id. at 123 (Bownes, J., dissenting) (emphasis in original).

85. See, e.g., Railroad Comm'n. of Tex. v. Pullman Co., 312 U.S. 496 (1941) (developed Pullman abstention doctrine: Federal courts should abstain from deciding unclear questions of state law). A detailed discussion of the Pullman doctrine is beyond the scope of this Note.

86. 863 F.2d at 122 (Bownes, J., dissenting).

87. 834 F.2d 884 (10th Cir. 1987).

88. Plaintiffs alleged that defendants had violated the Utah constitution and Utah statutes that prohibited employers from blacklisting employees, which is defined as keeping former employees from 
though blacklisting claims were currently unrecognized by Utah state courts. The court reasoned that if such a claim did exist under state law, "it is derived entirely from rights and duties created by state law and not from the terms, express or implied, of the collective bargaining agreement here invoked." 89 Unlike the First Circuit in the Jackson case, the Tenth Circuit recognized that although the CBA might be necessary to resolution of plaintiffs' claim, it would only be brought in "to show waiver or consent as a state-law defense to plaintiffs' allegations of blacklisting." Even if blacklisting turns out to be a negotiable state law right, plaintiffs' claim would not be preempted.

In addition, the Tenth Circuit focused on whether the "plaintiffs' complaint essentially alleges a violation of the collective bargaining agreement . . . "91 This is the key test under the proposed approach-whether the plaintiff could bring her state law claim without a CBA. If so, section 301 should have no preemptive power. This contrasts with the First Circuit's focus on whether resolution of Jackson's claim would involve CBA interpretation. It is interesting that the First Circuit decided Jackson after Lingle, since comparing Jackson and Bechtel indicates that the Supreme Court's language in Lingle has increased section 301's preemptive scope.

\section{A New Approach For Section 301 Claims}

\section{A. A Suggested Modification of the Lingle Preemption Test}

The Newberry and Jackson cases help show why the Lingle test should be modified. This Note proposes looking only at the plaintiff's state law right to determine whether section 301 preemption should occur. If the plaintiff asserts a state statutory or common law claim that is independent of the CBA in that it could be asserted without reliance on an employment contract, then section 301 should not preempt the claim. The courts would confront a much simpler task than examining both the state law and the CBA to determine whether an employee's action "substantially depend[s]"92 on CBA interpretation. Courts would declare section 301 preemption in only the following causes of action: (1) breach of contract, (2) breach of the implied covenant of good faith and fair dealing (for example, plaintiff Lueck's claim in Allis-Chalmers), and (3) claims that are clearly based directly on violation of the CBA (for example, if plaintiff's sole support for her intentional infliction of emotional distress claim is an

\footnotetext{
abtaining subsequent employment, by publishing lists of discharged employees "for the purpose of preventing such employee[s] from engaging in or securing similar or other employment from any other person, company or corporation." UTAH CODE ANN. \$ 34-24-1 (1988). See Bechtel, 834 F.2d at $885-86$ n.2.

89. Bechtel, 834 F.2d at 889

90. Id.

91. Id. at 887 .

92. Allis-Chalmers Corp. v. Lueck, 471 U.S. 202, 220 (1985).
} 
allegation that defendant breached the CBA). An alternative formulation of this test is if a non-union employee can maintain a cause of action under a state statute or under common law without reference to an employment contract, then a union employee should be afforded the same opportunity. ${ }^{93}$

In a case like Newberry, the proposed preemption test should not lead to results different from an accurate application of the Supreme Court Lingle test. ${ }^{94}$ But this will not be true in all section 301 cases. For example, the First Circuit's application of Lingle in Jackson was at least arguably correct, assuming that the GBA included terms relevant to Jackson's drug-testing claim. This Note's proposal would eliminate the following part of a footnote in Lingle which may have caused confusion about the preemptive scope of section 301:

While it may be true that most state laws that are not pre-empted by $\S 301$ will grant nonnegotiable rights that are shared by all state workers, we note that neither condition ensures nonpre-emption. It is conceivable that a State could create a remedy that, although nonnegotiable, nonetheless turned on the interpretation of a collectivebargaining agreement for its application. Such a remedy would be pre-empted by $\S 301 .^{95}$

The footnote may be referring to two situations where, under Lingle, a plaintiff's nonnegotiable state law claim would be preempted. First, an employer could assert a defense that genuinely requires interpretation of the CBA. For example, an employee could file a nonnegotiable state law claim against his employer for wrongful discharge due to handicap discrimination. The employer could answer that she discharged the employee because he violated the CBA's mandatory drug testing provision, not because of his handicap. To assess the employer's defense, the court should examine the CBA terms to see if the employee breached the agreement. The court would therefore need to interpret the GBA even though the employee asserted an independent state law claim. Under Lingle, the employee's claim would be preempted because it requires CBA interpretation.

In contrast, under the proposed approach, the employee's claim would not be preempted. His claim is not for breach of contract or breach of implied contractual rights, and it does not directly rely on the CBA. Allowing preemption in this type of case would encourage employers to as-

93. There are exceptions, however, when a state specifically limits a certain law or public policy to non-union employees. Otherwise, if an at-will employee (an employee without a contract) can bring a state law claim, then that claim by definition arises from law that is separate from an employment contract.

94. The Newberry court's mistaken holding stems directly from the confusion engendered by Lingle's overly broad preemption test, however. See supra note 77.

95. Lingle v. Norge Div. of Magic Chef, Inc., 108 S. Ct. 1877, 1882 n.7 (1988). 
sert invalid defenses to defeat employees' state law claims. In addition, a nonnegotiable handicap discrimination claim should not be characterized as a section 301 cause of action because that would require the employee to arbitrate his claim before filing suit. It is not the arbitrator's role to evaluate independent state law claims. The employee's handicap discrimination claim itself does not refer to CBA terms, and it is only the employer's defense that raises a federal question. The state court can assess this defense under its concurrent jurisdiction to interpret CBA's. ${ }^{86}$ The court must use federal law in interpreting the GBA, but after evaluating the validity of the employer's defense the court would use independent state law standards to resolve the employee's handicap discrimination claim.

A second example of a nonnegotiable state law right that requires CBA interpretation occurs when an element of the plaintiff's claim demands reference to CBA terms. A nonnegotiable handicap discrimination law that requires the plaintiff to demonstrate that he meets all the job requirements before proving wrongful discharge may necessitate examination of CBA job description provisions. ${ }^{97}$ Under the proposed test, the plaintiff's claim would not be preempted; however, since his state law claim is not completely independent from the CBA, he should be required to arbitrate the issues involving CBA interpretation before bringing a state court action. ${ }^{88}$

This approach would not allow the plaintiff to avoid the CBA arbitration provisions. At the same time, section 301 would not preempt his nonnegotiable claim. The heart of the plaintiff's claim is handicap discrimination, and the necessary CBA interpretation does not decide whether the employer violated state law. Once the arbitrator has interpreted how the CBA defined the relevant job requirements, the major state law questions remain as to whether the plaintiff met those requirements, and if so,

96. Charles Dowd Box Co. v. Courtney, 368 U.S. 502 (1962).

97. If the Sixth Circuit had accepted Chrysler's view that Michigan's Handicappers' Civil Rights Act (HCRA) "requires reference to the 'terms, conditions, and privileges of employment'-matters defined by the collective bargaining agreement," Fleming would be an example of such a case. See Smolarek v. Chrysler Corp., 879 F.2d 1326, 1332 (6th Cir. 1989). However, the Sixth Circuit ruled that these terms would not need to be defined in determining whether Chrysler violated the CBA, since the plaintiff had to show only "that Chrysler took adverse employment actions against him" because of his handicap. Id. at 1334 .

98. An arbitrator's role is to interpret the CBA, not state or federal law. See, e.g., Alexander v. Gardner-Denver Co., 415 U.S. 36 (1974) (in subsequent Title VII suit, court need not defer to arbitrator's decision regarding race discrimination). The arbitrator therefore should interpret the CBA's job requirements and leave the ultimate handicap discrimination question to the courts. In this case the plaintiff should be required to arbitrate the relevant CBA provisions before proceeding with his state law claim because his prima facie case relies on CBA terms. However, this does not make his claim a section 301 action because he is not alleging any breach of contract. In addition, an at-will employee would be able to bring an analogous lawsuit under the state handicap discrimination statute without relying on any contract-he would just need to show in another way that he fulfilled his employer's job requirements. Plaintiff's claim should therefore remain unpreempted. 
whether the employer's actions toward the plaintiff were motivated by handicap discrimination.

The proposed limitation of the scope of the Lingle preemption test is consistent with prior Supreme Court jurisprudence and with the purposes of section 301. State law claims should escape preemption as long as they do not rely on the existence of a CBA. If an independent right or remedy is nonnegotiable, then by definition it cannot be waived by contract. If an independent right is negotiable, then the CBA will require interpretation only in the assessment of the employer's defense, which will usually allege that the plaintiff waived the negotiable right.

\section{B. The Proposed Test Is Consistent with the Policies Underlying Fed- eral Preemption of State Labor Law}

When deciding in favor of federal preemption of state labor law claims in section 301 cases, the Supreme Court has advanced several major policy justifications. First, the Court has cited congressional intent: "[W]e cannot but conclude that in enacting $\S 301$ Congress intended doctrines of federal labor law uniformly to prevail over inconsistent local rules." ${ }^{99}$ Additionally, the Court has pointed out that allowing claims arising under section 301 to be determined by state laws that may be inconsistent with federal law would create problems in negotiating CBA's and in resolving grievances under CBA's. ${ }^{100}$ Therefore, section 301 preemption should not be limited only to suits alleging breach of contract but should extend to suits which depend on the existence of the CBA:

The interests in interpretive uniformity and predictability that require that labor-contract disputes be resolved by reference to federal law also require that the meaning given a contract phrase or term be subject to uniform federal interpretation. Thus, questions relating to what the parties to a labor agreement agreed, and what legal consequences were intended to flow from breaches of that agreement, must be resolved by reference to uniform federal law, whether such questions arise in the context of a suit for breach of contract or in a suit alleging liability in tort. ${ }^{101}$

Finally, parties should not be able to sidestep arbitration proceedings by basing their complaints in state law when they really constitute breach of the GBA claims. ${ }^{102}$

99. Local 174, Teamsters v. Lucas Flour Co., 369 U.S. 95, 104 (1962).

100. Id. at 103-04.

101. Allis-Chalmers Corp. v. Lueck, 471 U.S. 202, 211 (1985).

102. Several commentators have argued for increased federal preemption of state labor law in general and have included section 301 claims in their discussions. See, e.g., Gregory, supra note 4, at 507; Wheeler \& Browne, Federal Preemption of State Wrongful Discharge Actions, 8 Indus. REL. L.J. 1 (1986). 
All of these policy reasons are very important for state law claims that cannot exist without a CBA. There is no question that section 301 calls for the application of a uniform body of federal law when a court interprets CBA terms. None of these reasons has legitimate applicability, however, to preemption of claims that are based on independent state statutory or common law. ${ }^{103}$ If a state law claim does require some CBA interpretation, as in a case where the employer asserts that her employee breached the CBA, the courts can apply federal law to the employer's defense without any need for section 301 preemption. If a plaintiff's claim does not rely on a contract, then she is not unfairly avoiding arbitration procedures.

Thus, section 301 should not preempt independent or nonnegotiable state law claims, even if they could have been arbitrated under a GBA grievance procedure. Congress gave no explicit indication of its intent regarding the preemptive scope of section $301 .^{104}$ Preemption should therefore be limited to suits that fall under the language of the statute, claims which are "for violation of" CBA's. ${ }^{105}$ Other forms of labor law preemption doctrine will invalidate state laws that interfere with the purposes of the NLRA. ${ }^{108}$ Since Congress did not intend that the NLRA preempt all state law affecting employment relations, federalism concerns dictate that state laws which survive Garmon and Machinists preemption analysis and which do not rely directly on a CBA for enforcement remain unpreempted by section 301 .

Moreover, this Note's independent state rights preemption test reflects a concern for individual union employees' rights. In passing section 301, Congress did not intend to give union workers fewer rights than nonunion workers. ${ }^{107}$ If an employer could eliminate a union member's right to bring a state law action simply by asserting a defense requiring CBA interpretation, employees would see unionization as a less desirable alternative. States have been passing more laws protecting at-will employees, and if union members cannot take advantage of these laws, employees will perceive that unions limit their state law rights.

The proposed approach also maintains the effectiveness of arbitration. Often CBA's contain rights greater than those provided by state law, and

103. In addition, claims that involve only peripheral CBA interpretation should not be preempted. See supra Section IIIA. State courts can fulfill the uniformity requirement by using their concurrent jurisdiction under Charles Dowd Box Co. v. Courtney, 368 U.S. 502 (1962), to apply federal law to interpret the CBA.

104. See Allis-Chalmers, 471 U.S. at 208; H.R. REP. No. 510, 80th Cong., 1st Sess., reprinted in 1947 U.S. Code Cong. SERvice 1135, 1172.

105. 29 U.S.C. \& 185(a) (1982).

106. See supra text accompanying notes $20-30$.

107. See, e.g., Metropolitan Life Ins. Co. v. Massachusetts, 471 U.S. 724, 756 (1985) ("It would turn the policy that animated the Wagner Act [NLRA] on its head to understand it to have penalized workers who have chosen to join a union by preventing them from benefiting from state labor regulations imposing minimal standards on nonunion employers."). 
in such cases it would be advantageous for the plaintiff to file a grievance under the CBA. The arbitrator's role is to resolve disputes that involve alleged breaches of contract, not to interpret state or federal law. ${ }^{108}$

Furthermore, the proposed test will not disrupt the current collective bargaining system. The Garmon and Machinists preemption doctrines ensure that states cannot regulate certain mandatory bargaining subjects that would interfere too much with the collective bargaining process. Therefore, collective bargaining remains vital for determining issues such as wages, hours, and working conditions.

Adoption of the suggested approach will not unfairly disadvantage employers. The nonnegotiable and independent state laws in question were created to protect employees. Employers with unionized employees should not be able to avoid their obligations under these state laws by using section 301 preemption as a defense. Section 301 preemption does not present a choice of favoring employees or employers-it is limited to claims for breach of contract. Additionally, cases exist in which an employee voted against unionization, ${ }^{108}$ and believes that the union and the CBA do not protect his rights adequately. In such cases, it is more equitable to allow the aggrieved employee to bring a state law action that is viable without reference to the CBA. ${ }^{110}$

\section{GonClusion}

State and federal courts should adopt this preemption test: If a plaintiff asserts an independent or nonnegotiable state law claim in a case involving a section 301 question, then the claim is not preempted. There is no need for a court to look at the CBA. This approach has several advantages. First, it protects the individual rights of unionized workers by allowing them to assert nonnegotiable state law claims without federal preemption. Second, it allows states to regulate areas that Congress meant to leave within state jurisdiction. But at the same time, federal substantive law still governs CBA interpretation and breach of contract claims, which is imperative under section 301. Finally, the results of section 301 cases should become more consistent under the proposed approach, and section 301 preemption will be limited to claims arising from the CBA.

108. See supra note 98 .

109. A union only needs a majority of the workers to vote for unionization in order to organize a particular workforce.

110. Some pre-Lingle commentators agree that section 301 preemption should be more limited and advocate the well-pleaded complaint rule. See, e.g., Schwartz \& Parrot, A New Look at Labor Law Preemption: Unionized Employees' Claims in State Court, 7 ST. LouIS PuB. L. Rev. 297 (1988); Comment, Intimations of Federal Removal Jurisdiction in Labor Cases: The Pleadings Nexus, 1981 DukE L.J. 743 (advocates limiting federal jurisdiction in labor law preemption cases). 